This is an Accepted Manuscript of an article published by Taylor \& Francis in Knowledge Management Research and Practice on $12^{\text {th }}$ of December 2019, available online https://doi.org/10.1080/14778238.2019.1701961

\title{
Reimagining organisational conflicts through the metaphor of music
}

Paula Rossi*

${ }^{*}$ Faculty of Management and Business, Tampere University, Finland

Paula Rossi

Faculty of Management and Business, Tampere University

Postal address: Kanslerinrinne 1, 33100 Tampere, Finland

Tel.: +358 503187456

Email: Paula.Rossi@tuni.fi 


\section{Reimagining organisational conflicts through the metaphor of music}

In this theoretical article, the vital role of conflicts in knowledge creation is foregrounded, and the concept of conflict is reimagined using a metaphor of music. Theoretically, knowledge creation is understood as a process in which people, through institutionalisation, synthesise their conflicting institutional arrangements affecting their decisions, actions, and behaviour. Utilizing metaphor as a methodological choice, and combining music and organisational conflicts in an analytical framework offer ways to cross and move the boundaries between arts and science of organisational studies. As a result, conflicts are reimagined and reconceptualised as relational, felt meaning and lived experiences of differences in institutional arrangements. This reimagined concept shifts the focus of organisational conflicts from 'thingification' to human aspects underlying the sense-making of conflict experiences: the evolving story, identity, emotions and power relations.

Keywords: conflict, metaphor, knowledge creation, organisations, experiences, complexity

\section{Introduction}

Knowledge creation and organisational development are beset with conflicts (Rossi \& Tuurnas, 2019; Vince, 2014), which, indeed, are "a stubborn fact of organizational life” (Kolb \& Putnam, 1992, p. 311). In the predominant research paradigm, particularly studies on knowledge sharing and team performance (see, e.g., Chen, 2011; Chen, Zhang \& Vogel, 2011; Kakar, 2018), organisational conflicts are usually divided into task and relationship conflicts. It is recognised, however, that these typologies of conflicts are evidently interconnected, and have inconsistent impacts on team performance (Hinds \& Bailey, 2003; Kakar, 2018). 
To overcome these inconsistencies, Hinds and Bailey (2003) and Kakar (2018), for example, suggest that instead of dividing conflicts into task and relationship conflicts, organisational conflicts should rather be understood as dynamic processes. Indeed, the language and the metaphors we use to derive the concepts' meaning from, affect how conflicts are addressed both in organisational studies and, more importantly, in everyday organisational life. Metaphors, for example, have an impact on how we reason about conflict, what aspects of it are highlighted and hidden and what is understood as problems and solutions. (Andriessen, 2008.)

What the predominant research paradigm seems to suggest is a rather mechanistic approach, in which the organisational conflicts are understood as objective, neutral, countable, controllable and manageable things (Andriessen, 2008). Systemsthinking view on organisational conflicts, on the contrary, foregrounds the complexities of everyday organisational life, deepens the understanding about underlying structures and dynamics (Arnold, 2015), addresses the dynamic tensions, exposes multiple perspectives, assumes emergent causality (instead of linear, cause-effect), and illustrates the plurality of voices (Greenhalgh \& Papoutsi, 2018).

As a methodological choice, metaphor offers a way to address these tensions whilst revealing contradictions between meanings addressed to the concept of organisational conflicts (Elenurm, 2012). Thus, metaphors can be a powerful way to create knowledge, as they offer alternative ways of articulation by detaching the concept from its dominant vocabulary (Tsoukas, 2009). Using metaphor to explore concepts can hardly be perceived as a unique tool for creating new knowledge (Lakoff \& Johnson, 2003; Wurmser, 2011). In the organisational literature, however, the concept of organisational conflict has not been typically studied using the metaphor of music. 
This article calls attention to the vital role of conflicts in knowledge creation and organisational development, and utilises the metaphor of music as a way to manage imagination (Spender, 2008) about the concept of conflict. It is expected that music will emphasise the characteristics of conflicts that are present but hidden, and not yet articulated (Andriessen, 2008), giving rise to new language and insights about the concept. Primarily, the metaphor of music shifts the focus from the prevailing mechanistic approach of organisational conflicts to felt meaning and lived experiences: "I did not just hear music and appreciate it intellectually, I felt it deeply” (Kemler 2001, p. 1).

Pursuing new language and insights, the concept of organisational conflicts is reimagined through a metaphor of music by asking what underlying aspects the metaphor of music reveals about organisational conflicts and how people make sense of their conflict experiences. The article proceeds as follows: first, the theoretical framework, which concerns the role of conflicts in organisational development and knowledge creation, is presented. Second, metaphor as an analytical framework for reimagining concepts is proposed, and the metaphor of music is used as a methodological tool for critical analysis, revealing false argumentation and aspects of thinking that highlight certain features of conflicts and hide others (Andriessen, 2008).

As a result, a reimagined concept of conflicts as relational, felt meaning and lived experiences of differences in institutional arrangements, as well as the aspects of evolving stories, identity, emotions and power relations underlying the conflicts' felt meaning and lived experience are explored. In conclusion, the implications of the reimagined concept of conflicts for management paradigms and practices are discussed. 


\section{Framework}

\section{View of the predominant research paradigm on organisational conflicts}

In the predominant research paradigm, various typologies of organisational conflicts have been proposed (Speakman \& Ryals, 2010). Generally, conflicts are divided into four main levels: intergroup, intragroup, interpersonal and intrapersonal (Lewecki et al., 2011). Other scholars have classified conflicts based on whether they concern tasks or relationships (De Dreu \& Weingart, 2003; Jehn, 1997; Pinkley \& Northcraft, 1994; Reid, Bolman Pullins, Plank, \& Buehrer, 2004; Sessa, 1996; Van de Vliert, Nauta, Giebels, \& Janssen, 1999; Wall \& Nolan, 1986); are cognitive or affective (Amason, Thompson, Hochwarter, \& Harrison, 1995); content, relational or situational (Katz Jameson, 1999); or affective, cognitive or process-related (Speakman \& Ryals, 2010). In addition, emotional (Bradford et al., 2004) and goal conflicts (Tellefsen \& Eyuboglu, 2002) have been widely studied and used.

In the literature on the impact of conflicts on team performance and knowledge sharing (see, e.g., Chen, 2011; Chen, Zhang \& Vogel, 2011; Hinds \& Bailey, 2003; Kakar, 2018), conflicts are often classified into task and relationship conflicts. However, the findings of many of these studies are inconsistent (Hinds \& Bailey, 2003; Kakar, 2018). The interconnectedness of these typologies is recognised (Hinds \& Bailey, 2003; Kakar, 2018), and it is suggested that conflicts should rather be understood as dynamic processes (Hinds \& Bailey, 2003). Despite this, the predominant research paradigm seem to guide the way in which organisational conflicts are understood. These typologies are problematic, as they seems to suggest a mechanistic approach to understanding and studying the complexities of everyday organisational life, assuming linear causality and possibilities for command and control. 


\section{Conflicting institutional arrangements underlying organisational life}

Instead of understanding conflicts as destructive or 'deviant activit[ies]' (Putnam, 1997, p. 147), organisational scholars have long acknowledged that conflicts are embedded in interaction and, both a potential and necessity for organisational development. Evidently, numerous and versatile studies have been conducted on organisational conflicts. However, there are tensions between the terms and typologies of the predominant research paradigm of organisational conflicts (Speakman \& Ryals, 2010) and the experience-related, practical, complex nature of conflicts emerging from everyday interactions. This article focuses on the latter: conflicts embedded in interaction-and co-operation- are inseparable from human interaction and, thus, organisational life (Cooley, 1918; Follet, 1918/1998, 1924; Nonaka \& Toyama, 2003; Stacey, 2011). Pondy (1992) goes further, stating that conflicts are essential to organisations' existence, as an organisation consists of, drives, and develops from its diverse members.

According to Nonaka and Toyama (2003), knowledge is created when people with different goals and contexts are trying to understand evolving organisational life by interacting with people who hold different, contradictory views. Indeed, knowledge and knowledge creation in organisations reside in the interactions and social relations of human beings (Lehtimäki, 2017; Nonaka \& Takeuchi, 1995; Nonaka \& Toyama, 2005; Stacey, 2011). Conflicts, as contradictory institutional arrangements-values, beliefs, aims, and practices-of interacting individuals, are unavoidably shaping the organisational life, and allowing novelty to emerge (Blomgren \& Waks 2015; Mowles, 2011, 2015; Rossi \& Tuurnas, 2019; Stacey, 1992, 2011).

These varying and conflicting institutional arrangements underlie the decisions, behaviour and actions of people (Skålen, Aal, \& Edvardsson 2015; Vargo, Wieland, \& 
Akaka 2015) and are therefore essential for knowledge creation and organisational development. Theoretically, conflicts are an important subject to understand, and in practice, they are key drivers of knowledge creation and organisational development (Rossi \& Tuurnas, 2019; Skålen, Aal, \& Edvardsson 2015.)

\section{Knowledge creation and organisational development through institutionalisation}

Although it is well known that knowledge and knowledge creation are essential for organisations' success, less is known about the processes through which knowledge is actually created. Nonaka and Toyama (2003, p. 2) shed some light on these processes, conceptualising knowledge creation as ‘a dialogical process, in which various contradictions are synthesized through dynamic interactions among individuals, the organization, and the environment' (emphasis added). These scholars argue that the process of knowledge creation lies in synthesis of contradictions through dialectical thinking and acting (Nonaka \& Toyama, 2003), meaning that conflicts are prerequisites for knowledge creation and organisational development.

Deriving from systems-thinking paradigm, the process of synthesising contradictions is referred to as institutionalisation in service ecosystems literature. In institutionalisation, actors not only create but also disrupt and maintain institutional arrangements (Rossi \& Tuurnas, 2019; Trischler \& Charles 2019; Vargo, Wieland, \& Akaka 2015; Vink et al. 2019). Institutionalisation involves co-creational processes in which actors cope with and resolve the contradictions and inconsistencies that are foundational to all institutional arrangements (Vargo, Wieland, \& Akaka 2015).

Consequently, conflicts are notable differences in human interactions and more particularly in the thought processes of individuals experiencing them (Rossi, 2019), and knowledge creation can be located in inherently relational, yet individual thought 
processes. Spender (2008) refers to this idea in terms of managing one’s imagination and 'understanding and shaping the constraints on it as it impacts and engages the world' (p. 165). Conflicts, thus, emerge in the thinking processes of an individual, whilst one makes sense of the conflicts by questioning one's own thinking, experiences and the ways that one relates with others and the world (Chia; 1996; Heidegger, 1966; Rossi, 2019). Yet, the question of how actors make sense of these nested conflicts requires further exploration. Therefore, the aim of this article is to explore what underlying aspects the metaphor of music reveals about organisational conflicts and further to understand how people make sense of their conflict experiences.

\section{Methodology}

\section{Metaphor as a tool for knowledge creation}

Metaphor, as a tool for knowledge creation, addresses tensions whilst bridging different, contradictory domains of experience (Wurmser, 2011) and revealing contradictions between meanings (Elenurm, 2012). As a methodological choice, metaphor can trigger knowledge creation about organisational life in various ways. For this reason, it has been utilised in numerous organisational and leadership studies (e.g. Alvesson \& Spicer, 2011; Ehrich \& English, 2013; Lumby \& English, 2010; Morgan, 1986; Weick, 1998).

Metaphors can reframe concepts (Tsoukas, 2009), trigger articulation (Håkanson, 2007), help people perceive things differently (Ehrich \& English, 2013), reveal and manipulate meanings (Elenurm, 2012; Lumby \& English, 2010), manage imagination (Spender, 2008) and create new understandings 'and, therefore, new realities' (Lakoff \& Johnson 2003, p. 235). In this article, the metaphor of music is used as a methodological tool to reimagine organisational conflicts from novel perspectives. 


\section{Using a music as a metaphor: foregrounding felt meaning and lived experiences}

The language we use to describe conflicts, including the metaphors we use, affects how conflicts are managed in organisations. Metaphors can, for example, have an impact on how we reason about conflict, what aspects of it are highlighted and hidden and what is understood as problems and solutions. Thus, they can serve as a tool for critical analysis by revealing false argumentation (Andriessen, 2008.)

The way we talk about music also has an impact on our understanding. The function of language is clear and self-evident, but it does not capture the whole meaning of either conflicts or music (Van Niekerk \& Page-Shipp, 2014). As Mithen (2006, p. vii) said, 'I came to appreciate that it was not only music I was addressing but also language: it is impossible to explain one without the other’. Approaching music as felt meaning, Kemler (2001) argued that listeners cannot approach music solely as language:

Listeners do not merely hear the music and thus grasp its meaning; rather, they live its meaning. Indeed, listeners may also, through participating bodily in live or recorded musical performances, live tacitly known, felt social meanings—such as a sense of identity or place-in intensified fashion. (p. vi)

Musical meaning, according to Kemler (2001), is a complex phenomenon comprising at least three different realities: (1) physical reality, (2) social reality and (3) individual, psychological reality as an individual experience. In the third meaning, both previous realities ‘come into being and are maintained’ (Kemler, 2001, p. 9).

The predominant research paradigm's conceptualisation and typologies of conflicts do not capture the meaning, experiences and dynamic nature of conflicts and their role in knowledge creation and organisational development. Thus, it cannot reveal how knowledge is created through conflicts. In the following quote, Kemler (2001) 
discusses the disparity in theories and experiences of musical meaning, creating a basis for understanding the tensions between prevailing theories and experiences:

How could something that had merely seemed pretty come to mean so deeply? Nothing in my college music classes even approached an answer to this question. Those classes, theorizing about music and its meaning seemed overly cerebral, as if engaging with music were a matter that involved only the ears and brain. With my visceral, bodily way of experiencing music, I felt at odds with the scholarly musical culture I encountered there. I did not just hear music and appreciate it intellectually, I felt it deeply. Indeed, I lived it bodily. When playing music was at its best, I did not play the music, it played me. My experience as a flute performance major deepened the growing gap I felt between what was said about music in classes and how I experienced it. The ideas I learned in my theory classes seemed to have little to do with my goals in the practice room, where I struggled to transform plain notes into dynamic music. Although I enjoyed analyzing pieces for theory class, ultimately, those analyses did not even come close to touching the real power and meaning that music held for me. As a performer, it seemed to me that music theory—its language and approach—was a world somehow separate from mine. (pp. 1-2)

Regarding the tension between prevailing theories and experiences, the predominant research paradigm that guides studies on organisations and the conceptualisation and typology of conflicts hides more about organisational reality than it reveals.

Consequently, an appropriate metaphor for where the predominant conceptualisation of conflict derives meaning (Andriessen, 2008) could be conflict as ‘battle’ (Table 1). 


\begin{tabular}{|c|c|c|}
\hline $\begin{array}{l}\text { Source } \\
\text { domain }\end{array}$ & Reveals and assumes & Hides \\
\hline Battle & $\begin{array}{l}\text { Visible and addressable public events } \\
\text { Winners and losers } \\
\text { Right and wrong } \\
\text { Destructiveness } \\
\text { Avoidance } \\
\text { Negotiation } \\
\text { Power (over) }\end{array}$ & $\begin{array}{l}\text { Hidden, informal, private meanings, aspects } \\
\text { and emotions } \\
\text { Dynamic, evolving and relational processes } \\
\text { Power (with) }\end{array}$ \\
\hline & $\begin{array}{l}\text { Linear causality } \\
\text { Command and control }\end{array}$ & $\begin{array}{l}\text { Emergence } \\
\text { Interconnectedness } \\
\text { Uncertainty }\end{array}$ \\
\hline
\end{tabular}

Table 1. Characteristics of organisational conflicts that the metaphor of a battle reveals and hides.

First and foremost, the 'battle' metaphor seems to hide the human aspects of organisational conflicts: the hidden, informal, private meanings and emotions embedded in relational, evolving and dynamic processes of sense-making (Mather \& Yngvesson, 1980). In order to highlight these often-neglected aspects, this research utilises the metaphor of music, focusing on musical meaning and experience. The 'battle' metaphor sees conflicts as either generative or destructive; concerning either tasks or relationships; and often-dramatic confrontations and public events. In practice, however, most conflicts are embedded in interactions of everyday organisational life, occurring informally and out of sight (Kolb \& Putnam, 1992).

When reimagining the concept of conflict, the focus is on the meanings given to experiences. Even when a conflict might be traceable, for example, to the intergroup, intragroup, interpersonal or intrapersonal level (Lewecki et al. 2011), or when it concerns tasks rather than relationships, it should be emphasised that an individual always experiences it (Rossi, 2019). Therefore, the meaning of conflicts should be addressed by understanding conflicts as experiences (i.e. individual, psychological realities). This entails both the physical and social reality one experiences and 
foregrounds the hidden, informal, private and social meanings to bodily felt and lived experiences (i.e. the being in the world).

\section{Results: reimagining organisational conflicts through music metaphor}

The dimensions of form, volume, harmony, rhythm and texture are used to reimagine organisational conflicts (Table 2). These dimensions were drawn from the article ‘Music as a metaphor for organizational change’ (Mantere et al., 2007), in which they are used as a starting point for understanding how musical experience structures sensemaking. It is expected that musical meaning will enhance our understanding of organisational conflicts by shifting the focus from theories to felt meaning and lived experiences.

\begin{tabular}{ll}
\hline Dimensions & Musical meaning \\
\hline Form & $\begin{array}{l}\text { Plot of the musical piece, musical narrative/story } \\
\text { Theme is introduced, variations of the theme are played } \\
\text { Tensions emerge from not knowing the outcome }\end{array}$ \\
\hline Volume & $\begin{array}{l}\text { Intensity or force of the music } \\
\text { Intensity varies, contributing to the story } \\
\text { Silence is a level of volume }\end{array}$ \\
\hline Harmony & $\begin{array}{l}\text { The overall atmosphere created by different voices contributing to a whole } \\
\text { Can be strictly built in music or the music can allow harmony to break } \\
\text { Inconsistencies building the musical story }\end{array}$ \\
\hline Rhythm & $\begin{array}{l}\text { Habitual pattern and tempo of the music } \\
\text { Tensions emerge from breaking the patterns }\end{array}$ \\
\hline Texture & Overall quality of the sound \\
\hline
\end{tabular}

Table 2. The dimensions that structure musical meaning.

Form refers to the plot of a musical piece. This musical narrative or story is constructed of different parts, and, typically, a theme is introduced and slightly different variations on that theme are played. In the musical narrative, tensions emerge from not knowing its outcome or conclusion, creating anticipation for relaxation or release. 
Likewise, in organisational life, conflicts can be viewed as creating tension as well as the story of the organisation in everyday interactions, where both co-operation and conflicts are present and interwoven. Conflicts provoke a state and feeling of uncertainty as individuals do not know whether their experiences are going to meet their expectations. Thus, conflicts are essential parts of the story of organisational life, simmering below whilst people try to get things done together but sometimes bursting to the surface in publicly confrontations.

What seems to be a minor detail to someone 'reading the organisational story' from outside (e.g., someone not responding to an email) can-in the minds of those involved and in the broader context of the organisation's story-be an important clue for a conflict. Then, the form of the organisational story emerges: it is an interplay of cooperation and conflicts in organisational life in which uncertainty and unexpected events disrupt efforts to create a coherent, concluded story.

Volume indicates the intensity or force of music. In music, intensity is expected to vary to create a story. A musical piece can sound completely different if the volume of the musicians changes or certain parts of the form increase or decrease in volume. It is important to note that silence is also a volume: a powerful expression and a fundamental part of musical story.

Likewise, not all members can join and influence organisational life with the same force; it is expected that intensity will vary. Also, silence is an essential part of emerging story of the organisational life. When thinking about conflicts specifically, volume relates to the power relations inherent in experiences and to the intensity of events, experiences and emotions. In practice, volume indicates, for example, how publicly a conflict is occurring (e.g. shouting in a corridor or ignoring a co-worker), or how intensive is the emotion (e.g. anxiety, frustration, anger, fear or sadness) evoked by 
the conflict which in turn relates to how the conflict is addressed (e.g. ignorance, transfixion or reflexivity).

The volume of a conflict situation is subjective and thus experienced differently by the individuals involved. Additionally, the intensity of emotions varies and evolves in individuals' sense-making processes. Silence and temporal distance from conflicts are also needed when conflicts have to be understood and made sense of; in other words, silence and temporal distance are necessary for reflexivity and through it, the development.

In music, harmony is not about differences in voices, but about the overall atmosphere created by different voices as a whole. Depending on the style and musical era, harmony can be strictly built into composed music (e.g. in baroque) or music can allow harmony to break and flirt with inconsistencies, which are building the musical story.

As previously suggested, conflicts and complexity in organisations are the consequences of the fundamental diversity of human life, and these different individuals contribute to the organisational harmony. In the context of harmony, it is important to ask how an organisation deals with inconsistencies, i.e. conflicts. Does the management adhere to a coherent and consistent plan for the future, or does it allow conflicts to contribute to the evolving story of the organisation? Are conflicts treated as deviant activities that must be supressed or is diversity-and thus conflicts-allowed and valued?

Rhythm, the habitual pattern and tempo of music, offers insight and interesting possibilities for shaping the imagination and conceptualisation of conflicts. In both music and organisational life, tensions emerge from breaking habitual patterns. For example, conflict can urge participants to acknowledge that they are different, meaning that they have different rhythms and different possibilities for influencing organisational 
life. A person can also experience conflict with the rhythm or logic of practices or weekly, monthly and yearly routines. Furthermore, daily life features a constant flow of emails, requests, interruptions and unexpected events that need to be dealt with, setting and breaking rhythm.

In addition, the interplay between actions and pauses, talking and listening, standing still and moving, influencing and being influenced, creates the rhythm of organisational life. Again, temporal distance and silence during the pause phase are important to the evolving story and are needed to make sense of conflicts as incompatible rhythms. It is also important to draw attention to the role of one's body in producing and understanding rhythm, as rhythm is a bodily felt experience.

The texture of music emerges from the combination of different instruments, rhythm, volume and harmonic material of a music piece. Thus, texture can be understood as the overall quality of the sound. In organisational life, texture is related to organisational structures, hierarchies, physical reality, and the institutional arrangements of actors. For example, someone might want to ask how conflicts have affected the overall story of an organisation and what conflicts might indicate about the dominant institutional arrangements or how the structures and practices of the organisation foster interaction and dialogue between different members. As a conclusion, the Table 3 summarises how the dimensions of musical meaning discussed above can be applied to organisational conflicts. 


\begin{tabular}{ll}
\hline Dimension & What it reveals about conflicts \\
\hline Form & $\begin{array}{l}\text { Story emerges from the interplay of cooperation and conflicts } \\
\text { Emerging uncertainty } \\
\text { Expectations vs. experiences }\end{array}$ \\
\hline Volume & $\begin{array}{l}\text { Individuals have different volumes } \\
\text { Intensity of experienced conflicts, events and emotions varies }\end{array}$ \\
& $\begin{array}{l}\text { Volume is experienced and interpreted subjectively } \\
\text { Silence and time impact sense-making and reflexivity } \\
\text { Power relations and imbalances }\end{array}$ \\
\hline Harmony & $\begin{array}{l}\text { Fundamental diversity of human life } \\
\text { Harmony constituting of different individuals co-operating } \\
\text { Conflicts either suppressed or valued }\end{array}$ \\
\hline Rhythm & $\begin{array}{l}\text { Individuals have different rhythms } \\
\text { Routine tasks, practices and structures creating rhythm } \\
\text { Tensions emerge from differences between people and breaking of habitual patterns } \\
\text { Silence and time impacting sense-making and reflexivity } \\
\text { Bodily felt meanings, experiences and emotions in producing and understanding rhythm }\end{array}$ \\
\hline Texture & $\begin{array}{l}\text { Physical and social reality combined in experiences } \\
\text { Structures, hierarchy, power relations and institutional arrangements } \\
\text { Institutional arrangements of individuals in relation to others create texture }\end{array}$ \\
\hline & \\
\hline &
\end{tabular}

Table 3. How the dimensions of musical meaning relate to organisational conflicts.

\section{Synthesis: Sense-making of the felt meanings and lived experiences of organisational conflicts}

\section{Shifting the focus on human aspects}

The synthesised conceptualisation that reveals characteristics about conflicts through the metaphor of music (Andriessen, 2008) initiates a shift away from rationally addressed, controlled, managed or avoided events (conflicts as battles) towards relational, felt meanings and lived experiences of differences in institutional arrangements (conflicts as music). Further, this reimagined conceptualisation draws attention to the underlying and interconnected human aspects, which structure the sense-making of organisational conflicts: an evolving story, identity, emotions and power relations (Table 4). 


\begin{tabular}{|c|c|}
\hline Revealed through the metaphor of music & $\begin{array}{l}\text { Underlying } \\
\text { human aspects }\end{array}$ \\
\hline $\begin{array}{l}\text { Expectations and experiences } \\
\text { Sense-making } \\
\text { Different institutional arrangements of individuals creating conflicts } \\
\text { Breaking patterns by doing things differently } \\
\text { Relational, dynamic and essential nature of conflicts } \\
\text { Hidden meanings, silence and time contribute to the meaning of conflicts }\end{array}$ & Evolving story \\
\hline $\begin{array}{l}\text { Fundamental diversity of individuals } \\
\text { Subjective interpretation, expectations and experiences } \\
\text { Sense-making through self and identity }\end{array}$ & Identity \\
\hline $\begin{array}{l}\text { Often-negative, intensive, bodily felt emotions provoke sense-making } \\
\text { Emotions of anxiety and uncertainty provoked by conflicts } \\
\text { The intensity of provoked emotions depends on one's identity and previous } \\
\text { experiences }\end{array}$ & Emotions \\
\hline $\begin{array}{l}\text { Individuals with unequal possibilities to influence institutional arrangements } \\
\text { Power inherent in interactions, contributing to expectations and experiences } \\
\text { Bodily felt and experienced rhythm }\end{array}$ & Power relations \\
\hline
\end{tabular}

Table 4. The interconnected, relational human aspects underlying the felt meaning and lived experience of conflicts.

To begin with, musical meaning is a subjective, lived experience: no one other than the listener can describe which emotions it awoke, how the rhythm felt, what textures were preferred or how its temporality affected. As Reimer (2003) states, the value of music emerges through immediate experiences with meaningful sounds. Likewise, the value of conflicts for knowledge creation and organisational development emerges through lived experiences and felt meanings.

Although experiences are subjective, it is essential to emphasise that they are simultaneously unavoidably emerging and evolving in relation to the life's physical and social aspects (Kemler, 2001; Rauhala, 1998), in processes of sense-making. Here, sense-making is defined as a process in which people are trying to understand experienced conflicts. Many studies have describe sense-making as something that enables people to engage in change, make decisions and find innovative solutions to problems (e.g. Maitlis et al., 2013). 


\section{Evolving stories underlying the sense-making}

The understanding of organisations as 'storytelling systems that are performed into existence' (Frandsen et al. 2017, p. 1) focuses on the stories that people tell whilst making sense of their experiences (Herman, 2009; Walsh, 2018). Storytelling is a basic human strategy for coping with change, processes and time (Hyvärinen, 2016; Vaara \& Tienari, 2011), and stories have the potential to capture expectations and experiences as the 'felt quality of lived experiences’ (Herman, 2009 p. 138).

Conflict, as an evolving story, is a process that transforms over time because of the actors’ contradictory experiences, interests and interpretations (Hyvärinen, 2016; Mather \& Yngvesson, 1980). Neither music nor conflict is an event that occurs at a specific time and place that people can address; rather they are processes in which the embedded hidden, informal and private meanings, aspects, emotions and evolution are important (Rossi, 2019). Notably, stories about conflict experiences and the way conflicts meaning evolves are always related to the stories of others, and the relations between these stories are constantly evolving as people interact and try to make sense of what is happening and why. It is in these processes of relating where knowledge can emerge.

When people think about music and how it is experienced, it becomes clear that they cannot label music as only enthralling or mediocre, or as silence or noise. Music is still music, even if there is no audience, and its melody includes silence as a necessary story element. Likewise, conflict cannot be understood or categorised solely as being generative or destructive, cognitive or affective, or to concern merely tasks or relationships: it moves between these extremes over time and space. For example, an outcome can shift from destructive to generative as people make sense of their experiences. Shifts also occur between the hidden and visible, unaddressed and 
addressed, and expected and experienced. Storytelling is a way of navigating the gap between these extremes: in otherwise complex and randomly seeming everyday life, storytelling thus provides a way to make sense of the complexity in and around organisations and ourselves (Frandsen et al., 2017).

\section{Identity underlying the sense-making}

Whether music is interpreted, understood or felt as inspiring or boring depends on the individual who is interpreting, understanding and feeling it. This also applies to conflicts: the identity of an individual, which is built upon their previous experiences, influences and is influenced by their experiences and understanding of conflict. Experienced conflicts often pose threats to the experiencer's identity and are thus difficult to confront whilst attempting to protect the identity. It is perfectly understandable for people to address identity-threatening, contradictory experiences by creating coherent stories that match their existing stories and self-concepts (Kreiner, Hollensbe, \& Sheep, 2006; Maitlis et al., 2013).

The interconnectedness of conflicts and identity often gives rise to intense bodily emotions, which are commonly left unaddressed and unarticulated. Our bodies possess knowledge in the form of intuition, emotions and physical skills (Ehrich \& English, 2013), but we are not accustomed to addressing this knowledge. Moreover, the emotions aroused during conflicts and the intensity of these emotions depend on the experiencer's identity and previous experiences in the context of one's life and are thus subjective.

\section{Emotions underlying the sense-making}

It might not be a conflict itself that triggers an experiencer's sense-making process, but the bodily felt, intense (and often-negative) emotions evoked by conflicts. Maitlis, 
Vogus and Lawrence (2013) stated that emotions should be explored as a critical part of the sense-making process because they indicate the need for and support this process. As many studies have shown (Baumeister, Bratslavsky, Finkenauer, \& Vohs, 2001; Labianca \& Brass, 2006; Maitlis et al., 2013; Rozin \& Royzman, 2001), intense negative emotions receive more attention and must be made sense of more often than positive emotions, such as contentment or joy.

Intense negative emotions aroused by experienced conflicts are often rapid and, as such, are not fruitful grounds for sense-making. However, triggered by conflicts as negative events, negative emotions are made sense of in slower, reflexive sensemaking processes. Reflexivity and temporal distance allow generative sense-making to take place in what Baumeister, Vohs, Nathan DeWall, and Zhang (2007) refer to as a dualprocess approach. Emotions can also be regarded as the emotional energy released by conflicts. This energy can serve as a cognitive and behavioural awakening for the experiencer that leads to transformation (Hargrave \& Van de Ven, 2017).

In contrast to conflicts, which often generate rapid negative emotions, music often evokes positive emotions in the listener. Hence, in regards to emotions, music is an inadequate analogy to conflicts. However, both are characterised by a relation between experience, emotions and identity; in both music and conflict, the intensity of an experience and the emotions aroused are filtered through the experiencer's identity. As Kemler stated (2001, p. 8), 'Musical meaning occurs in this intransitive, resonant manner; it does not necessarily mean something, it simply means. Through bodily experience, music resonates with and in the inner self of the individual listener'. Human behaviour-and thus the sense-making about conflicts-are more greatly extent affected by emotions than by rational reasoning; the emotional tail wags the rational dog (Kahneman, 2011). Recognising the role of emotions in conflicts calls for 
self-awareness and awareness of embodied knowledge in one's own and others' stories as well as congruency with and authenticity in articulated and unarticulated ways of relating to others.

\section{Power relations underlying the sense-making}

Importantly, self-awareness, reflexivity and relating to others are thought processes characterised by inherited ethical, responsible and critical actions that involve values and power relations (Cunliffe \& Jun, 2005; Ehrich \& English, 2013). As the rhythm and volume varies, so do the possibilities for people to affect knowledge creation and the development of organisational life. All interactions are characterised by power relations, as power is integral to people’s experiences (Vince, 2014), and not all people have equal possibilities to influence especially in complex, multi-actor settings (Haynes, 2018).

Power relations both hinder and enable behaviours and actions (Vince, 2014), and they affect the actors' possibilities to change their values, beliefs, aims and practices. Power relations and institutional arrangements are thus intervened: people have unequal power to choose, of whose and which institutional arrangements are created, maintained, disturbed or, often unconsciously, followed (Rossi and Tuurnas, 2019).

\section{Discussion: a paradigm shift from mechanistic events to systems-thinking view on organisational conflicts}

For one aiming to manage knowledge creation and organisational development, the traditional, mechanistic paradigm leads to difficulties in dealing with the complexity, uncertainty and paradoxes of organisational life. Uncertainty is a consequence of the complexity, and complexity arises from humans, who are simultaneously rational and 
emotional, thinking and feeling, co-operative and conflicting, and reflective and bodily experiencing beings. (Rossi, 2019.)

Therefore, instead of dehumanising organisational conflicts as objective, neutral, mechanistic, countable, controllable and manageable things-what Andriessen (2008, p. 8) refers to as ‘thingification'-we need to reground our thinking to profoundly human aspects of organisational life. This calls for a paradigm shift towards systems-thinking view, which, instead of reductionist approach's typologies, focuses on complexities of everyday organisational life, and deepens the understanding of underlying structures and dynamics (Arnold, 2015). Systems-thinking view on organisational conflicts thus recognises the importance of exploring dynamic tensions, exposing multiple perspectives, assuming emergent causality (instead of linear, cause-effect), and illustrating the plurality of voices (Greenhalgh \& Papoutsi, 2018).

\section{Managerial implications}

Utilising the systems-thinking view, the reimagined conceptualisation of organisational conflicts has important implications for understanding the organisation-related, fundamental phenomena of leadership and management (Tjosvold, 2008). The vital role of conflicts in knowledge creation and organisational development highlights the dynamic, relational nature of organisational life, and, as Nonaka and Toyama (2003) suggested, knowledge management and knowledge creation are profoundly embedded in interaction and occur through reflexivity regarding differences.

Consequently, in management research and practice the attention shifts to what is happening in everyday interaction and how conflicts, as necessities for knowledge creation, contribute to the relational process of organisational life within the complex, living systems. It becomes thus necessary to consider whether conflicts are seen as deviant activities that need to be supressed or as expressions of diversity, and whether 
the manager sees him- or herself capable as of guiding development with a coherent strategy or allows and values inconsistencies and conflicts.

First, the importance of bodily experienced and unarticulated aspects-hidden and private meanings and emotions-to management practices need emphasizing. According to Ladkin (2008) and Sinclair (2005), leadership is often theorised as a disembodied practice of rational behaviour and brain activity, but it should be addressed as an often unarticulated, embodied activity, as 'understanding, reasoning and meaning are based in bodily experience in the world' (Kemler, 2001, p. 3). Managers often try to overcome disturbing emotions aroused by conflicts by implementing traditional management strategies, which do not work very well in uncertain and complex settings. Therefore, attempts to create typologies, manage, control and avoid conflicts become efforts to manage, control and avoid the people's experiences, identities and emotions aroused by conflicting opinions, values, beliefs and practices (Rossi, 2019).

It is important for managers to be aware of individual evolving stories about the relational, felt meanings and lived experiences of conflicts, as well as their connectedness to change at both the individual, organisational and systems levels. In other words, it is important to foreground subjective experiences and allow space for 'multiple realities and multiple voices' (Ropo \& Sauer, 2008, p. 569). The challenge for managers is to turn their attention to the dynamics of organisational life through selfawareness and reflexivity.

Nevertheless, the sense-making process, occurring through self-awareness and reflexivity, is tightly intertwined with one’s identity. Especially for those in leadership positions, practicing self-awareness has social costs, as it might require publicly admitting confusion and uncertainty and may potentially raise questions about whether the manager is competent (Blatt, Christianson, Sutcliffe, \& Rosenthal, 2006; Maitlis et 
al., 2013). It is also noteworthy that self-awareness and reflexivity requires efforts and thus can be a difficult and unpleasant processes that may change the way one thinks (Maitlis et al., 2013). This might be the most difficult, but essential, task to do.

Emotions are located in people's bodies, and their bodies communicate emotions, even if they are not articulated or consciously addressed (Damasio, 2000; Merleau-Ponty, 1962). Humans are highly skilled in picking up these unspoken messages and unconsciously responding to them in interaction (Stacey, 2005). This recalls the awareness of knowing in and through the body (Merleau-Ponty, 1962; Ropo \& Sauer, 2008). The rhythm of the organisational life is experienced in and through the body and affected by the rhythm of others (Ropo \& Sauer, 2008). Leading and managing are embodied activities in which participants unavoidably communicate through their gestures, facial expressions, voice tones and body movements (Ladkin, 2008).

Within a systems-thinking view that foregrounds organisational dynamics and interaction, power relations are always present and embedded in experiences, underlying actions and behaviour. A key element that motivates people to develop organisational life is the struggles over power and position (Skålen, Aal, \& Edvardsson, 2015). Managers naturally hold positions of power (Rossi \& Tuurnas, 2019), and can hinder or enable behaviour and actions, thus shaping the possibilities for development (Vince, 2014). Therefore, it is vital to consider how managers utilise their power when knowledge creation and organisational development are intended. Instead of using or abusing positional and hierarchical power over employees, the importance of the embodied role, position and power of managers (i.e. the referent power or power with) needs emphasizing (Follett, 1941). 


\section{Disclosure statement}

No potential conflict of interest was reported by the author.

\section{References}

Alvesson, M., \& Spicer, A. (2011). Metaphors we lead by: Understanding leadership in the real world. New York: Routledge.

Amason, A. C., Thompson, K. R., Hochwarter, W. A., \& Harrison, A. W. (1995).

Conflict: An important dimension in successful management teams.

Organizational Dynamics, 24(2), 20-35.

Andriessen, D. G. (2008). Stuff or love? How metaphors direct our efforts to manage knowledge in organizations. Knowledge Management Research and Practice, 6(1), 5-12.

Arnold, R. (2015). A definition of systems thinking: A systems approach. Procedia Computer Science, 44, 669-678.

Baumeister, R. F., Bratslavsky, E., Finkenauer, C., \& Vohs, K. D. (2001). Bad is stronger than good. Review of General Psychology, 5(4), 323-370.

Baumeister, R. F., Vohs, K. D., Nathan DeWall, C., \& Zhang, L. (2007). How emotion shapes behavior: Feedback, anticipation, and reflection, rather than direct causation. Personality and Social Psychology Review, 11(2), 167-203.

Blatt, R., Christianson, M. K., Sutcliffe, K. M., \& Rosenthal, M. M. (2006). A sensemaking lens on reliability. Journal of Organizational Behavior, 27(7), 897917.

Blomgren, M., \& Waks, C. (2015). Coping with contradictions: Hybrid professionals managing institutional complexity. Journal of Professions and Organization, 2(1): 78-102. 
Bradford, K. D., Stringfellow, A., \& Weitz, B. A. (2004). Managing conflict to improve the effectiveness of retail networks. Journal of Retailing, 80(3), 181-195.

Chen, Z. (2011). The interactive effects of relationship conflict, reward, and reputation on knowledge sharing. Social Behaviour and Personality, 39(10), 1387-1394.

Chen, Z., Zhang, X., \& Vogel, D. (2011). Exploring the underlying processes between conflict and knowledge sharing: A work-engagement perspective. Journal of Applied Psychology, 41(5), 1005-1033.

Chia, R. (1996). The problem of reflexivity in organizational research: Towards a postmodern science of organization. Organization, 3, 31-59.

Cooley, C. H. (1918). Social process. New York: Scribner \& Sons.

Cornelissen, J. P., Oswick, C., Thøger Christensen, L., \& Phillips, N. (2008). Metaphor in organizational research: Context, modalities and implications for researchintroduction. Organization Studies, 29(1), 7-22.

Cunliffe, A. L., \& Jun, J. S. (2005). The need for reflexivity in public administration. Administration \& Society, 37(2), 225-242.

Damasio, A. R. (2000). The feeling of what happens: Body and emotion in the making of consciousness. New York: Harcourt Brace \& Company.

De Dreu, C. K. W., \& Weingart, L. R. (2003). Task versus relationship conflict, team performance, and team member satisfaction: A meta-analysis. Journal of Applied Psychology, 88(4), 741-749.

Ehrich, L. C., \& English, F. W. (2013). Leadership as dance: A consideration of the applicability of the 'mother' of all arts as the basis for establishing connoisseurship. International Journal of Leadership in Education, 16(4), 454481. 
Elenurm, T. (2012). Open space as a knowledge metaphor and a knowledge sharing intervention. Knowledge Management Research and Practice, 10(1), 55-63.

Follett, M. P. (1918/1998). The new state. University Park, PA: Pennsylvania University Press.

Follett, M. P. (1924). Creative experience. New York: Longmans Green.

Follett, M. P., Metcalf, H. C., \& Urwick, L. (1941). Dynamic administration: The collected papers of Mary Parker Follett. New York: Harper.

Frandsen, S., Kuhn, T. \& Lundholt, M. W. (2017). Counter-narratives and organizations. New York \& London: Routledge \& Taylor \& Francis Group.

Greenhalgh, T., \& Papoutsi, C. (2018). Studying complexity in health services research: Desperately seeking an overdue paradigm shift. BMC Medicine, 16(1), 1-6.

Greenwood, R., Diaz, A. M., Li, S. X., \& Lorente, J. C. (2010). The multiplicity of institutional logics and the heterogeneity of organizational responses. Organization Science, 21(2), 521-539.

Håkanson, L. (2007). Creating knowledge: The power and logic of articulation. Industrial and Corporate Change, 16(1), 51-88.

Hargrave, T. J., \& Van de Ven, A. H. (2017). Integrating dialectical and paradox perspectives on managing contradictions in organizations. Organization Studies, 38(3-4), 319-339.

Heidegger, M. (1966). Discourse on thinking: A translation of gelassenheit. (J. M. Anderson and E. Hans Freund, Trans.). New York: Harper \& Row.

Herman, D. (2009). Basic elements of narrative. Malden, MA: Wiley-Blackwell. Hinds, P. J., \& Bailey, D. E. (2003). Out of sight, out of sync: Understanding conflicts in distributed teams. Organization Science, 14(6), 615-632. 
Hyvärinen, M. (2016). Expectations and experientiality: Jerome Bruner's 'Canonicity and Breach’. Storyworlds, 8(2), 1-25.

Jehn, K. A. (1997). A qualitative analysis of conflict types and dimensions in organizational groups. Administrative Science Quarterly, 42(3), 530-557.

Kahneman, D. (2011). Thinking, fast and slow. New York: Farrar, Straus and Giroux.

Kakar, A. K. (2018). How do team conflicts impact knowledge sharing? Knowledge Management Research and Practice, 16(1), 21-31.

Katz Jameson, J. (1999). Toward a comprehensive model for the assessment and management of intraorganizational conflict: Developing the framework. International Journal of Conflict Management, 10(3), 268-294.

Kemler, D. (2001). Music and embodied imagining: Metaphor and metonymy in western art music (Doctoral dissertation, University of Pennsylvania). Retrieved from: http://repository.upenn.edu/edissertations/1184

Kolb, D. M., \& Putnam, L. L. (1992). The multiple faces of conflict in organizations. Journal of Organizational Behavior, 13(3), 311-324.

Kreiner, G. E., Hollensbe, E. C., \& Sheep, M. L. (2006). Where is the “me” among the "we”? Identity work and the search for optimal balance. Academy of Management Journal, 49(5), 1031-1057.

Labianca, G., \& Brass, D. J. (2006). Exploring the social ledger: Negative relationships and negative asymmetry in social networks in organizations. Academy of Management Review, 31(3), 596-614.

Ladkin, D. (2008). Leading beautifully: How mastery, congruence and purpose create the aesthetic of embodied leadership practice. Leadership Quarterly, 19(1), 3141. 
Lakoff, G., \& Johnson, M. (2003). Metaphors we live by. Chicago: University of Chicago Press.

Lehtimäki, H. (2017). The strategically networked organization: Leveraging social networks to improve organizational performance (1st ed.). Bingley, UK: Emerald. Retrieved from https://tamcat.finna.fi/Record/tamcat.914036

Lewicki, R. J., Barry, B., \& Saunders, D. M. (2011). Essentials of negotiation. (6th ed.). New York: McGraw-Hill.

Lumby, J., \& English, F. W. (2010). Leadership as lunacy: And other metaphors for educational leadership. Thousand Oaks, CA: Corwin Press.

Maitlis, S., Vogus, T. J., \& Lawrence, T. B. (2013). Sensemaking and emotion in organizations. Organizational Psychology Review, 3(3), 222-247.

Mantere, S., Sillince, J. A. A., \& Hämäläinen, V. (2007). Music as a metaphor for organizational change. Journal of Organizational Change Management, 20(3), 447-459.

Mather, L., \& Yngvesson, B. (1980). Language, audience, and the transformation of disputes. Law \& Society Review, 15(3/4), 775-821.

Merleau-Ponty, M. (1962). Phenomenology of perception. London: Routledge \& Kegan Paul.

Mithen, S. (2006). The singing Neanderthals: The origin of music, language, mind and body. London: Phoenix.

Morgan, G. (1986). Images of organization. Beverly Hills, CA: Sage Publications.

Mowles, C. (2011). Rethinking management: Radical insights from the complexity sciences. Farnham, UK: Gower.

Mowles, C. (2015). Managing in uncertainty - complexity and the paradoxes of everyday organizational life. London: Routledge. 
Nonaka, I., \& Takeuchi, H. (1995). The knowledge-creating company: How Japanese companies create the dynamics of innovation. New York: Oxford University Press.

Nonaka, I., \& Toyama, R. (2003). The knowledge-creating theory revisited: Knowledge creation as a synthesizing process. Knowledge Management Research and Practice, 1(1), 2-10.

Nonaka, I., \& Toyama, R. (2005). The theory of the knowledge-creating firm: Subjectivity, objectivity and synthesis. Industrial and Corporate Change, 14(3), 419-436.

Nonaka, I., von Krogh, G., \& Voelpel, S. (2006). Organizational knowledge creation theory: Evolutionary paths and future advances. Organization Studies, 27(8), 1179-1208.

Pinkley, R. L., \& Northcraft, G. B. (1994). Conflict frames of reference: Implications for dispute processes and outcomes. Academy of Management Journal, 37(1), $193-205$.

Pondy, L. R. (1992). Reflections on organizational conflict. Journal of Organizational Behavior, 13(3), 257-261.

Putnam, L. L. (1997). Productive conflict: Negotiation as implicit coordination. In C. De Dreu \& E. Van De Vliert (Eds.), Using conflict in organizations (1st ed.). London: SAGE Publications.

Rauhala, L. (1998). Ihmisen ainutlaatuisuus [The uniqueness of humanity]. Helsinki: Yliopistopaino.

Reid, D. A., Bolman Pullins, E., Plank, R. E., \& Buehrer, R. E. (2004). Measuring buyers’ perceptions of conflict in business-to-business sales interactions. Journal of Business \& Industrial Marketing, 19(4), 236-249. 
Reimer, B. (2003). A philosophy of music education (3rd ed.). Englewood Cliffs, NJ: Prentice Hall.

Ropo, A., \& Sauer, E. (2008). Dances of leadership: Bridging theory and practice through an aesthetic approach. Journal of Management \& Organization, 14(5), $560-572$.

Rossi P. (2019). Conflicts in leading change: Towards a practice of reflexive transformation. In A. Kangas, J. Kujala, A. Heikkinen, A. Lönnqvist, H. Laihonen, \& J. Bethwaite (Eds.), Leading change in a complex world: Transdisciplinary perspectives (pp. 165 -181). Tampere: Tampere University Press.

Rossi, P., \& Tuurnas, S. (2019). Conflicts fostering understanding of value co-creation and service systems transformation in complex public service systems. Public Management Review. doi: 10.1080/14719037.2019.1679231

Rozin, P., \& Royzman, E. B. (2001). Negativity bias, negativity dominance, and contagion. Personality and Social Psychology Review, 5(4), 296-320.

Sessa, V. I. (1996). Using perspective taking to manage conflict and affect in teams. The Journal of Applied Behavioral Science, 32(1), 101-115.

Sinclair, A. (2005). Body possibilities in leadership. Leadership, 1(4), 387-406.

Skålen, P., Aal, K. A., \& Edvardsson, B. (2015). Cocreating the Arab Spring: Understanding transformation of service systems in contention. Journal of Service Research, 18(3), 250-264.

Speakman, J., \& Ryals, L. (2010). A re-evaluation of conflict theory for the management of multiple, simultaneous conflict episodes. International Journal of Conflict Management, 21(2), 186-201. 
Spender, J.-C. (2008). Organizational learning and knowledge management: Whence and whither? Management Learning, 39(2), 159-176.

Stacey, R. D. (2005). Experiencing emergence in organizations: Local interaction and the emergence of global pattern. London: Routledge.

Stacey, R. D. (2011). Strategic management and organizational dynamics. The challenge of complexity. Gosport, UK: Ashford Colour Press.

Tellefsen, T., \& Eyuboglu, N. (2002). The impact of a salesperson’s in-house conflicts and influence attempts on buyer commitment. Journal of Personal Selling and Sales Management, 22(3), 157-172.

Tjosvold, D. (2008). The conflict-positive organization: It depends upon us. Journal of Organizational Behavior, 29(1), 19-28.

Trischler, J., \& Charles, M. (2019). The Application of a Service Ecosystems Approach to Public Policy Analysis and Design: Exploring the Frontiers, Journal of Public Policy \& Marketing 38(1), 19-35.

Tsoukas, H. (2009). A dialogical approach to the creation of new knowledge in organizations. Organization Science, 20(6), 941-957.

Vaara, E., \& Tienari, J. (2011). On the narrative construction of multinational corporations: An antenarrative analysis of legitimation and resistance in a crossborder merger. Organization Science, 22(2), 370-390.

Van De Vliert, E., Nauta, A., Giebels, E., \& Janssen, O. (1999). Constructive conflict at work. Journal of Organizational Behavior, 20(4), 475-491.

Van Niekerk, C., \& Page-Shipp, R. (2014). Improving the quality of meetings using music. Total Quality Management \& Business Excellence, 25(11-12), 1382-1394.

Wall, V. D., \& Nolan, L. L. (1986). Perceptions of inequity, satisfaction, and conflict in task-oriented groups. Human Relations, 39(11), 1033-1051. 
Walsh, R. (2018). Sense and wonder: Complexity and the limits of narrative understanding. In R. Walsh \& S. Stepney (Eds.). Narrating complexity. Cham, Switzerland: Springer.

Vargo, S. L., Wieland, H., \& Akaka, M. A. (2015). Innovation through institutionalization: A service ecosystems perspective. Industrial Marketing Management 44, 66-72.

Vink, J., Edvardsson, B., Wetter-Edman, K., \& Tronvoll, B. (2019). Reshaping mental models - Enabling innovation through service design. Journal of Service Management, 30(1), 75-104.

Vince, R. (2014). What do HRD scholars and practitioners need to know about power, emotion, and HRD?. Human Resource Development Quarterly, 25(4), 409-420.

Weick, K. E. (1998). Improvisation as a mindset for organizational analysis. Organization Science, 9(5), 543-555.

Wurmser, L. (2011). Metaphor as conflict, conflict as metaphor. Psychoanalytic Inquiry, 31(2), 107-125. 